\title{
On Some Problems of Sex-Oriented Linguistic Behavior in Modern English (A Sociolinguistic Approach)
}

\author{
Gohar Harutyunyan, Ashkhen Mkrtchyan \\ Yerevan State University
}

T anguage is the most powerful emblem of social behavior, the way we use it speaks of who we are, what we are and where we come from. Preference for this or that linguistic item, even a single word, may give us much information about the person's being in general - his/her sex, age, cultural ties, education, family status, sexual orientation, character and so on. Briefly defined, this is the speaker's effect on language, or, in a broad sense, the effect of the society on language. The present article, which is written from the sociolinguistic perspective, is an attempt to study language in relation to society.

Sociolinguistics ${ }^{1}$ focuses on the study of the effect of certain aspects of society - cultural norms, expectations and context - on the way language is used. Thus sociolinguistic analysis covers any point that deals with language rules and its users - from broadly based international relations to narrowly defined interpersonal ones.

Being a fundamental factor of human life, sex differences do reflect all aspects of reality, including language. Thus, in Non-Western and Western communities men's and women's languages, which are formed on the basis of sex-exclusive and sex-preferential speech features have been differentiated.

The initial identification of female register was done by Robin Lakoff in 1975, who argued that the style of language served to maintain women's (inferior) role in society. A later refinement of this argument was that gender differences in language reflected a power difference. However, both these perspectives consider the language style of men as normative implying that women's style is inferior (Lakoff 1975).

In her book "Language and Woman's Place", Robin Lakoff set up a chart of female speech features, a thesis that has been of great use and help to generations of sociolinguists. Lakoff distinguished women's language in a number of ways including:

1. Hedging - uncertainty and lack of authority, e.g. 'sort of';

2. Super polite forms - 'If you don't mind, please may you...?';

3. Hypercorrect grammar and pronunciation - e.g. women avoid 'ain't' or double negatives;

4. Tag questions - show that women want approval of their utterances e.g. 'I'm coming with you, all right?';

5. Speaking in italics - women use exaggerated intonation or stress for emphasis, expressing uncertainty, e.g. 'I am very frustrated with you';

6. Empty adjectives, e.g. 'divine, lovely, adorable, delightful sweetie';

7. Use of implication - Lakoff claimed women use this because they do not feel the authority to give orders, e.g. 'It's cold in here, isn't it?' instead of 'Shut the window!'; 
8. Special lexicon - Lakoff states that such words are trivial and evidence of the fact that women have been allowed control over unimportant things, e.g. purple of blue women would say 'lilac' or 'violet';

9. Question intonation in declarative statements - women raise the pitch of their voice at the end of statements expressing uncertainty, e.g. 'Dinner's in half an hour?';

10. Lack of sense of humor - Lakoff argued that women don't joke much or understand jokes;

11. Speaking less frequently - men speak more often than women, which proves women to be less certain of themselves;

12. Indirect speech - 'Wow, I'm so thirsty!' instead of asking for a drink;

13. Avoiding coarse language of expletives;

14. Apologies - 'I'm sorry, but I think that...' .

The present article is an attempt to focus on Robin Lakoff's female language universals through an empirical research, for which movies serve as the main source. Five movies are chosen as context for study, they are 'Eyes Wide Shut'", 'Pleasantville', 'Black Swan' ${ }^{4}$, 'Seven Pounds' ${ }^{5}$, 'Remember Me' ${ }^{6}$. From the points suggested by Lakoff as female speech features seven features were chosen to question- either prove or deny their actuality in movie language. They are the use of weak expletives, female adjectives, intensifiers, hedges, hypercorrect forms and patterns signaling the value of politeness.

Let us begin the discussion with the coarse language. Our analysis shows that movie women use strong expletives. Even tape-recorded conversations prove that roughly 8090 spoken words each day are expletives, and if once women could do with "oh, Jesus" or "damn", "my goodness" and the kind of weak expletives, today their speech abounds in profanities like "fuck", "buggering" and the like. Thus, at least in movies women's weak oral aggression does not work:

$$
\begin{array}{rr}
\text { - You loser asshole, I gonna 'ave a fuckin' stunning night. } & \text { (PV) } \\
\text { - Aw, Doctor almighty cock titty squeezer, you don' think she ever has } \\
\text { any buggering fantasies about you? }
\end{array}
$$

The next issue under discussion is hedges. The use of mitigating devices is typical of both sexes, the main difference being in the choice of the device: women prefer hedges like "I guess", "you know", "they say", "like", while men use passive constructions and weasels. In fact, movies also prove that women fall for hedges more often than men do.

- I guess it would no be this way if your father was here. I do not actually think I am to blame. People say men are. I think I have a wrong life.

Then we concentrate on women's adjectives, i.e. adjectives generally expected in women's rather than men's speech. These are a group of adjectives which, besides their specific and literal meanings, have another use, that of indicating the speaker's approba- 
tion or admiration for something. However, in movies the use of female or the so called 'empty' adjectives is no way apt to be damaging male reputation. They abuse 'loud' adjectives to make their speech more picturesque and impressive:

$$
\begin{aligned}
& \text { - I was thinking of wearing that red thing ... it is not slutty, it is gor- } \\
& \text { geous. Hmm, adorable. } \\
& \text { - My sweetest day. }
\end{aligned}
$$

The words, which add to the force of utterance, are also of particular interest. Intensifiers give additional emotional content to the utterance (or the word they modify). By using intensifiers speakers express their feelings. Thus, as a rule, women's speech serves an affective function, while men's - referential.

- Hey! you were dead amazing. Seriously, I know that things got all messed up between us, I mean, really holy shit completely blew me away!

Movies are a happy soil for the study of super-polite forms, apologies and indirect requests. Women give utmost value to politeness. They are for negative politeness - they always tend to save the interlocutor's face, as they are afraid of losing theirs. This accounts for the use of super-polite forms, through which they mitigate the force of their utterance.

\section{- Would you mind my asking you the geography of the Main Street?}

'Sorry' tops in 10 most frequently used words by women. Women do apologize even if there is no need to do so, while men say sorry when they really are. From the psychological point of view the great use of 'sorry' and 'thanks' accounts for female humans' being conscious of 'codex' imposed on them by the society: a trifle fault damages 'right' behavior.

- Excuse me, what's outside Pleasantville?

Men talk more than women do, as women let the interlocutors dominate the conversation. Men tend to disagree, women seek agreement and see disagreement as more threatening to relationship, this is why women prefer indirect speech acts to direct ones. They always communicate more than they actually say thinking directness is not a marker of politeness.

- Could you please tell me about what's outside Pleasantville?

- Oh, sweetie, I would like you to have breakfast before you leave. 
Another lakoffian point that is of interest is the use of tag questions more by women than by men. Tags are indicators of politeness suggesting either confidence or lack of it. Women use tags more than men do as these types of sentences provide a means to avoid committing oneself thereby also to avoid facing conflicts with the addressee. The most interesting thing in connection with tag questions is the intonation pattern: women use rising intonation (/)- marker of uncertainty; men use falling intonation (\)- marker of confidence.

- You don't remember my name, do you? / (female speaking)

- Your name's Nina, isn't it? \(male speaking)

Hyper-correct pronunciation and grammar were once typical and desired traits of female speaking. Hyperusage of hyper-correct grammar and intonation indicates women's "indulged desire to be posher than posh". However, movie-women break away of this 'posh' path and show up a very interesting linguistic behavior: they come to be more incorrect both in grammar and in pronunciation (intonation) than men. In brief terms, hyperurbanizm does not work with movie-women.

- I don't have no idea of what happened, me also is excited. (double negation)

- She asked me if I were for the chief part. (use of subjunctive)

The research on movie conversations shows that the test of lakoffian "female language universals" appears to be not so much actual in movie-women's speech. If we take into consideration that Lakoff made her research in the 1970s, it is not surprising that within years profanity, 'impoliteness', both grammatical and phonological mistakes are nowadays considered quite normal in women's speech because of today's overlap of sexroles and the change of women's social role.

\section{Notes:}

1. Sociolinguistics is the study of language in social contexts and the study of social life through linguistics. The main focus of sociolinguistics is the effect of the society on language. It was pioneered by William Labov (US) and Basil Bernstein (UK) in 1960s.

2. EWS-Eyes Wide Shut is a 1999 based upon the 1926 (Dream Story), which was written by . The film was directed, produced and co-written by . The story, set in and around New York City, follows the sexually charged adventures of Dr. Bill Harford (T. Cruise), who is shocked when his wife, Alice (N. Kidman), reveals that she had contemplated an affair a year earlier.

3. PV - Pleasantville is a 1998 American fantasy written, produced, and directed by . The film stars Tobey Maguire, Reese Witherspoon, William H. Macy, Joan Allen. 
David and Jennifer find themselves in a colorless town, but as it gets, the town changes totally.

4. BS - Black Swan is a 2010 American psychological thriller film directed by Darren Aronofsky and starring Natalie Portman, Vincent Cassel, and Mila Kunis. Its plot revolves around a production of Tchaikovsky's Swan Lake ballet by a prestigious New York City company. The production requires a ballerina to play both the innocent White Swan and the sensual Black Swan. One dancer, Nina (Portman), is a perfect fit for the White Swan, while Lily (Kunis) has a personality that matches the Black Swan. When the two compete for the parts, Nina finds a dark side to herself.

5. 7P-Seven Pounds is a 2008 film, directed by . stars as a man who sets out to change the lives of seven people, as in an accident he caused died 7 people his beloved included. was Rosario Dawson, Woody Harrelson, and Barry Pepper star.

6. RM - Remember Me is a 2010 American romantic coming of age drama film directed by Allen Coulter, and screenplay by Will Fetters. It stars Robert Pattinson, Emilie de Ravin, Chris Cooper, Lena Olin, and Pierce Brosnan. Tyler falls for Ally, as the film goes we see good-fly in son-father as well as daughter-father relationship. The film ends tragically with Tyler's death on 9/11.

\section{References:}

1. Butler, J. (1990) Gender Trouble. New York: Rutledge.

2. Coates, J. \& Cameron, D. (1986) Women in their Speech Communities. London: Longman.

3. Holmes, J. (1992) Women's Talk in Public Contexts. // Discourse and Society. London: Longman.

4. Labov, W. (1972) Sociolinguistic Patterns. Philadelphia: Pennsylvania University Press.

5. Lakoff, R. (1975) Language and Women's Place. New York: Harper and Row.

6. Tannen, D. (1990) You Just Don't Understand. // Women and Men in Conversation. New York: Wm. Morrow.

7. Trudgill, P. (1995) Sociolinguistics: An Introduction to Language and Society. London: Hardmondsworth.

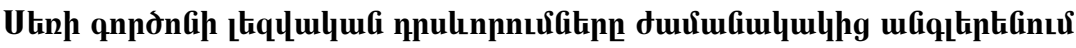 (hufipuptequmutiulyufi únuntignıu)}

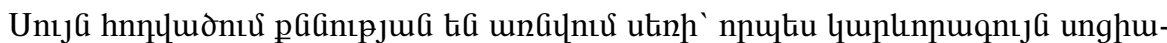

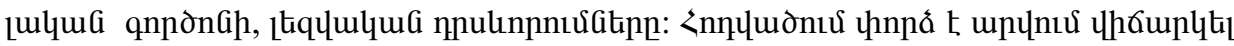

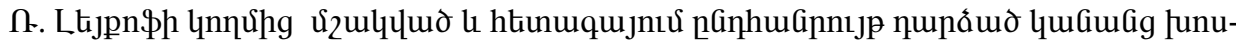

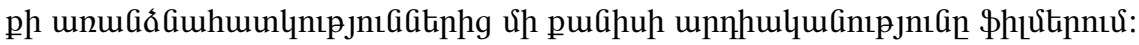

